\title{
The Behavior of Potato Mid-Early Varietis Concerning Production when Treatments with Unconventional Products Are Performed (2013- 2014)
}

\author{
Ioan BRAŞOVEAN, Ioan OROIAN*, Antonia ODAGIU, Cristian IEDERAN \\ Faculty of Agriculture. University of Agricultural Science and Veterinary Medicine, Cluj - Napoca, \\ Romania \\ *Corresponding author: neluoroian@gmail.com
}

Bulletin USAMV series Agriculture 72(2)/2015

Print ISSN 1843-5246; Electronic ISSN 1843-5386

DOI 10.15835/buasvmcn-agr: 11759

\begin{abstract}
The potato is a plant which has great importance for human nutrition, animal feed and industrial processing. Mid early potato varieties studied (Amelia, Robusta, Christian, Dacia, Impala and Roclas) reacted differently to the application of treatments wuth conventional and unconventional products. As is clear from the data obtained, the application of both conventional and unconventional treatments, the varieties taken into study, reacted differently to the application of the same treatments.We conclude that this is due to the effects of remineralization, rebalancing and regenerating of the metabolic processes of plants, nutrient content of main products, secondary products and trace elements acting on the plant cells, even in relatively unfavorable climatic conditions for potato culture.
\end{abstract}

Keywords: potato, mid-early varietis, unconventional products, production.

\section{INTRODUCTION}

The potato is a plant which has great importance for human nutrition, animal feed and industrial processing [Ştefan, 2005]. Rightly considered the ,second bread' of the world, the potato is one of the nicer food [Mogârzan et al., 2004]. Today, with the population explosion, potato, along with several other plants is hope for mankind ensuring adequate food supplies, competing with the most important food: cereals, meat, fruit.

This paper aims to identify and quantify the behavioral aspects of semi late potato varieties in terms of production, the application of unconventional treatments with products.

\section{MATERIALS AND METHOD}

To achieve its designed objectives polifactorial experience, type $2 \times 6 \times 6$ in three repetitions, to identify the conduct semi late potato varieties in production facilities, the application of treatments with products where FACTOR - the experimental years 2013 or 2014; Factor B - semi late potato varieties: Robusta, Amelia, Christian, Dacia, Impala, Roclas; Factor $\mathrm{C}$ - unconventional products: Bordeaux mixture, Bionat, Biostar, Glutaxim, Terra Sorb Foliar, Maxiroot

In the experiments conducted at the Research and Development Station Jucu, in addition to application behavior varieties produced conventional and unconventional treatments, was pursued the behavior variety of different earliness groups in specific climatic conditions of the area in terms of production. To determine the production of potato were set three stages:

I. In the first stage, the main activity was the collection, this activity is carried out during the 
potato harvesting optimum and suitable climatic conditions. Two weeks before harvest, it was taken an action preceding the harvest namely creeping destruction, with the main role to step up the tubers. Actual harvest was done manually on each variation and repetition in part, to avoid production losses and damage to tubers.

II. The second step consisted in counting tubers on each variant (to determine the average weight of a tuber for each variety), their calibration in 3 fractions (high, middle tiers, small) and weighing tubers from each.

III. A third phase focused on the preparation of a database with the results you get in phase II. After the creation of the database, the results obtained after weighing $(\mathrm{kg})$ per variant and repetition were reported in part per hectare. For reporting data obtained per hectare was used „simple rule of three" following formula:

Q/var (kg) $\mathrm{S}$ var $(\mathrm{m} 2)$

$\mathrm{X}$. $10000 \mathrm{~m} 2$

$X====>X$ în $\mathrm{kg} /$ hectar, were

Q / var - the weight of each variant tubers Svar - variable surface
Results were statistically interpreted and formed the basis of determining the effectiveness of treatment products applied on conventional and unconventional production and the attack in the varieties studied.

\section{Productivity of mid early potato varieties in experimental years}

In these experiments, we used six mid early potato varieties, namely Amelia, Robusta Christian, Dacia, Impala and Roclas. Next, to assess the behavior of these varieties in terms of production, the application of foliar greenhouse phytoprotective against major pathogens. The experimental results obtained on the production are shown in Table 1

The data in Table 1 it appears that, following the application of foliar treatments, the yields obtained in 2013, 3 of the 6 varieties under study are higher than the yields obtained in 2014. In 2013 there were positive registered significant differences compared to control (Robusta variety) variety Dacia positive and significant differences in the varieties Amelia and Christian. In 2014, there were negative significant differences from the control varieties and Impala Dacia and a significantly negative difference unica variety. Amelia and Christian varieties were not

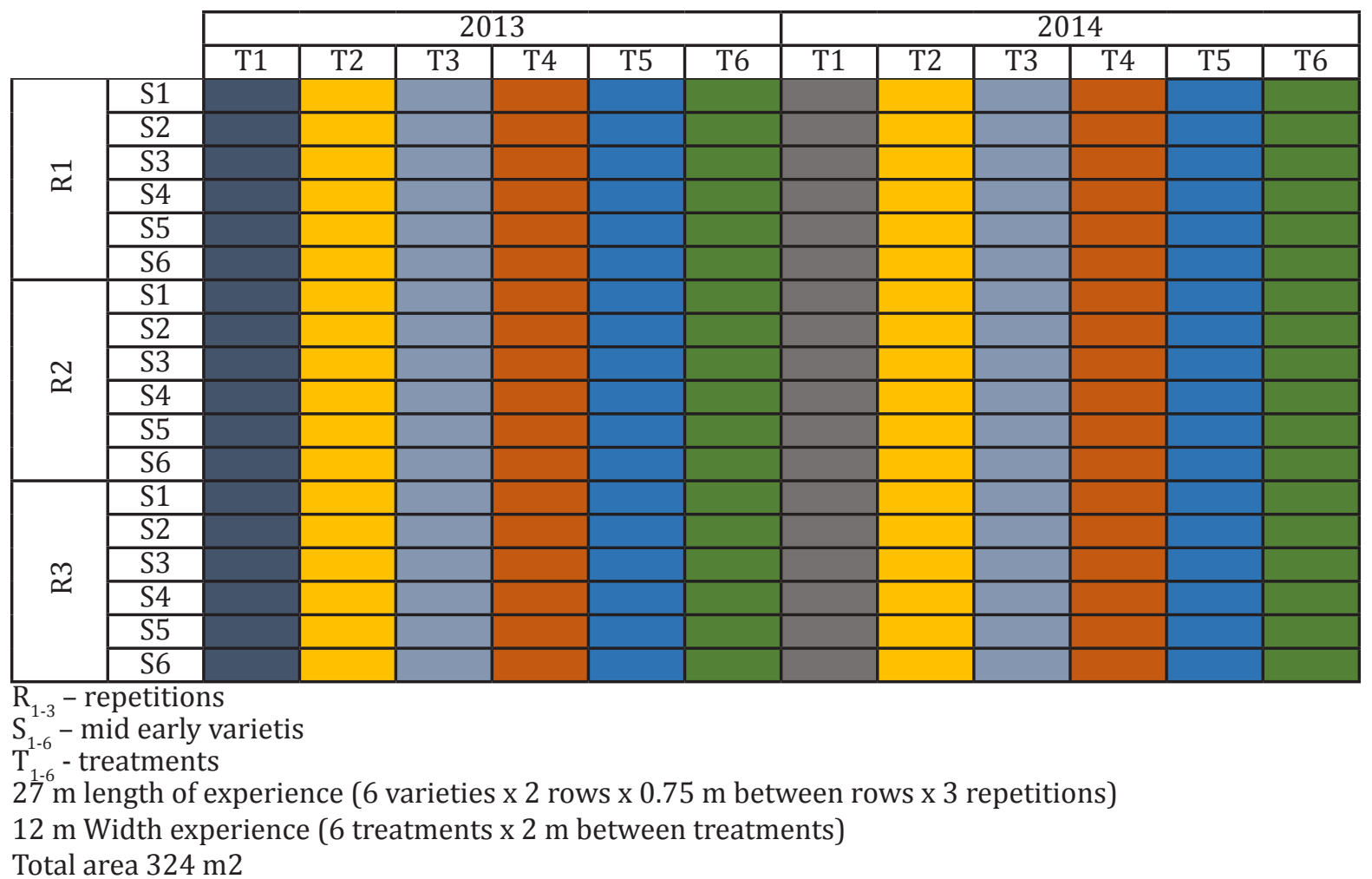

Fig. 1 Experimental scheme 
The main features of mid-early varieties taken in the study

\begin{tabular}{|c|c|c|c|c|c|c|c|}
\hline $\begin{array}{l}\text { Nr. } \\
\text { crt. }\end{array}$ & Issues on the main features & Robusta & Amelia & Christian & Dacia & Impala & Roclas \\
\hline 1 & Maturity & Mid-early & Mid-early & Mid-early & Mid-early & Mid-early & Mid-early \\
\hline 2 & Productive potential & 52,4 t/ha & $70,6 \mathrm{t} / \mathrm{ha}$ & $70,6 \mathrm{t} / \mathrm{ha}$ & $95,6 \mathrm{t} / \mathrm{ha}$ & $\begin{array}{l}\text { Ridicată } \\
\text { High }\end{array}$ & $65,9 \mathrm{t} / \mathrm{ha}$ \\
\hline 3 & $\begin{array}{l}\text { Resistance to common scab } \\
\text { (Synchitrium endobioticum) }\end{array}$ & Resistant & Resistant & Resistant & Resistant & Resistant & Resistant \\
\hline 4 & Tuber shape & Roundly & $\begin{array}{c}\text { Roundly egg- } \\
\text { shaped }\end{array}$ & Egg-shaped & $\begin{array}{l}\text { Roundly egg- } \\
\text { shaped }\end{array}$ & $\begin{array}{l}\text { Long egg- } \\
\text { shaped }\end{array}$ & Egg-shaped \\
\hline 5 & Bark color & Red & Red & Red & Yellow & Yellow & Yellow \\
\hline 6 & Core color & Yellow & Yellow & Yellow & Yellow & Yellow & Yellow \\
\hline 7 & $\begin{array}{l}\text { Resistance to Potato } \\
\text { Leafroll Virus(PLRV) }\end{array}$ & Resistant & Resistant & Sensitive & Resistant & $\begin{array}{l}\text { Susceptible to } \\
\text { twisting }\end{array}$ & Resistant \\
\hline 8 & $\begin{array}{l}\text { Resistance to Potato Virus } \\
\text { Y (PVY) }\end{array}$ & Resistant & Very resistant & $\begin{array}{l}\text { Middle } \\
\text { resistant }\end{array}$ & Very resistant & $\begin{array}{l}\text { Good } \\
\text { resistance }\end{array}$ & $\begin{array}{l}\text { Middle } \\
\text { resistant }\end{array}$ \\
\hline 9 & $\begin{array}{l}\text { Resistance to Late } \\
\text { Blight(Phytophthora } \\
\text { infestans) }\end{array}$ & $\begin{array}{l}\text { Middle } \\
\text { resistant }\end{array}$ & East sensitive & East sensitive & $\begin{array}{l}\text { Sensitive on } \\
\text { leaf }\end{array}$ & $\begin{array}{l}\text { Susceptible on } \\
\text { leaf }\end{array}$ & $\begin{array}{l}\text { Middle } \\
\text { resistant }\end{array}$ \\
\hline
\end{tabular}

Tab.1. Productivity of mid early potato varieties in experimental years

\begin{tabular}{|c|c|c|c|c|c|c|c|c|}
\hline \multirow{2}{*}{$\begin{array}{l}\text { Year } \\
\text { Variety }\end{array}$} & \multicolumn{4}{|c|}{2013} & \multicolumn{4}{|c|}{2014} \\
\hline & $\begin{array}{l}\text { Production } \\
\text { (t/ha) }\end{array}$ & $\begin{array}{l}\text { Diffe- } \\
\text { rence }\end{array}$ & $\begin{array}{l}\text { Semnifi- } \\
\text { cance }\end{array}$ & $\begin{array}{c}\text { Duncan } \\
\text { Test }\end{array}$ & $\begin{array}{l}\text { Production } \\
\text { (t/ha) }\end{array}$ & $\begin{array}{l}\text { Diffe- } \\
\text { rence }\end{array}$ & $\begin{array}{l}\text { Semnifi- } \\
\text { cance }\end{array}$ & $\begin{array}{c}\text { Duncan } \\
\text { Test }\end{array}$ \\
\hline Robusta & 16.36 & 0,00 & Mt. & $\mathrm{A}$ & 21,89 & 0,00 & Mt. & EF \\
\hline Amelia & 18.60 & 2,23 & $*$ & $\mathrm{BCD}$ & 21,96 & 0,07 & - & $\mathrm{EF}$ \\
\hline Christian & 18.55 & 2,19 & $*$ & BCD & 22,46 & 0,58 & - & $\mathrm{F}$ \\
\hline Dacia & 20.09 & 3,73 & $* * *$ & $\mathrm{DE}$ & 16,96 & $-4,93$ & 000 & $\mathrm{AB}$ \\
\hline Impala & 17.07 & 0,71 & - & $\mathrm{AB}$ & 17,61 & $-4,28$ & 000 & $\mathrm{ABC}$ \\
\hline Roclas & 15.76 & $-0,60$ & - & $\mathrm{A}$ & 19,39 & $-2,50$ & 0 & $\mathrm{CD}$ \\
\hline DL (p 5\%) & & & 1,30 & & & & 1,30 & \\
\hline DL (p 1\%) & & & 1,77 & & & & 1,77 & \\
\hline DL (p $0.1 \%$ ) & & & 2,39 & & & & 2,39 & \\
\hline
\end{tabular}

significantly different from control. Figure 2 shows that, compared to the average yields recorded in the two years The experimental, Robusta varieties, Amelia, Christian, Impala and unica experimental highlighted in 2014 while in 2013, only the variety Dacia s recorded higher yields than the average.

Production differences in the experimental years may be justified by the fact that rainfall records, especially during the growing season has been uneven, registering temperatures higher values from the annual average.
The influence of some conventional and unconventional treatments applyed on mid early potato varieties upon production

As seen in Table 1, the yields recorded in two experimental years were different. Climatic data recorded Research Station Jucu, underline the fact that during the potato growing season, rainfall records were distributed unevenly, while temperatures have exceeded the annual average. In Table 2 shows the yields obtained during experiments and the average yields obtained, the 


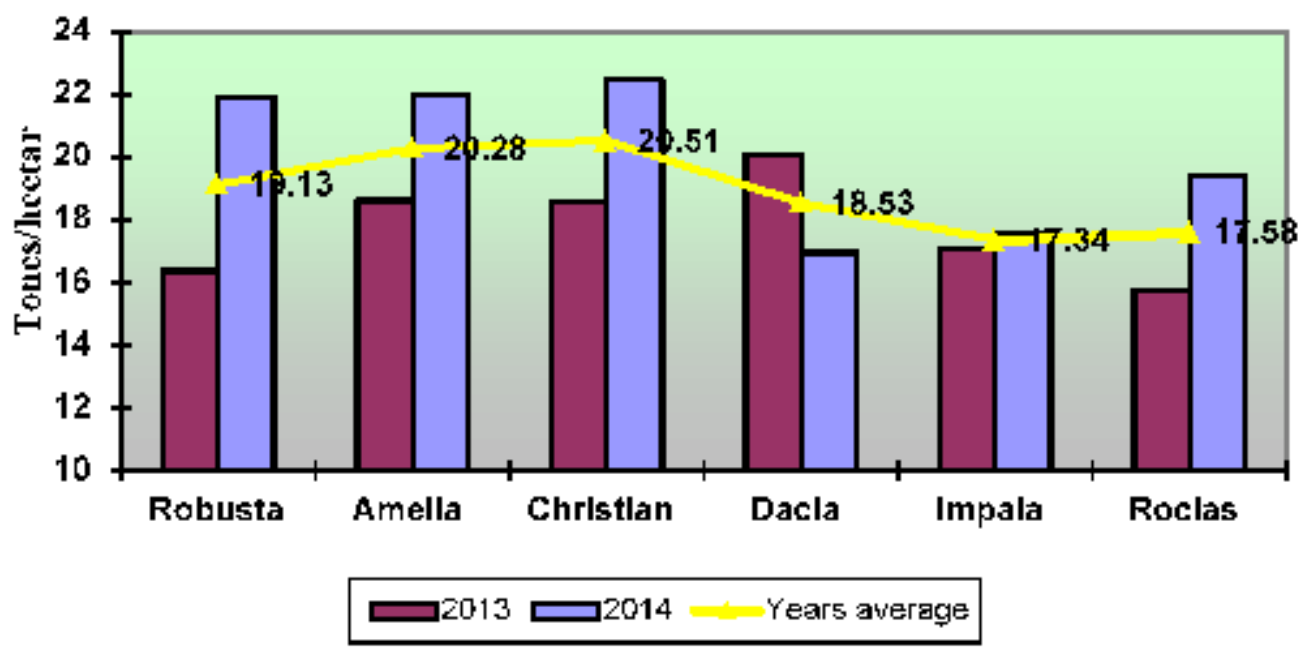

Fig. 2. Productivity of mid early potato varieties compared with the years averagea

Tab. 2. The influence of some conventional and unconventional poducts, applyed on mid early varieties upon production

\begin{tabular}{|c|c|c|c|c|c|c|c|c|c|c|c|c|}
\hline \multirow{2}{*}{$\begin{array}{l}\text { Year } \\
\text { Treatment }\end{array}$} & \multicolumn{4}{|c|}{2013} & \multicolumn{4}{|c|}{2014} & \multicolumn{4}{|c|}{ Average 2013-2014 } \\
\hline & 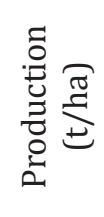 & 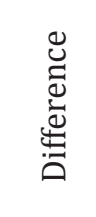 & 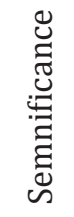 & 芯 & 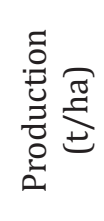 & 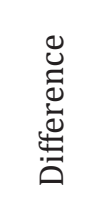 & 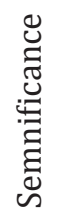 & $\stackrel{\widetilde{J}}{\leftrightarrows}$ & 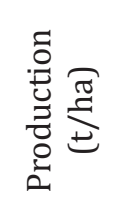 & 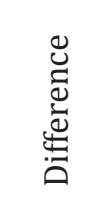 & 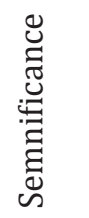 & 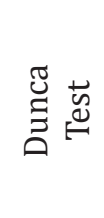 \\
\hline Bordeaux mixture & 19.33 & 0.00 & Mt. & EFG & 22.29 & 0.00 & Mt. & I & 20.81 & 0.00 & Mt. & EF \\
\hline Bionat & 18.43 & -0.90 & - & DEFG & 18.49 & -3.81 & 000 & DEFG & 18.46 & -2.35 & 000 & $\mathrm{CD}$ \\
\hline Biostar & 18.58 & -0.75 & - & DEFG & 18.80 & -3.49 & 000 & DEFG & 18.69 & -2.12 & 00 & $\mathrm{CD}$ \\
\hline Glutaxim & 18.88 & -0.45 & - & DEFG & 14.47 & -7.82 & 000 & A & 16.67 & -4.14 & 000 & $\mathrm{AB}$ \\
\hline Terra Sorb Foliar & 16.98 & -2.36 & 0 & BCDE & 16.76 & -5.53 & 000 & $\mathrm{BCD}$ & 16.87 & -3.94 & 000 & $\mathrm{AB}$ \\
\hline Maxiroot & 16.88 & -2.45 & 0 & $\mathrm{BCD}$ & 16.88 & -5.42 & 000 & $\mathrm{BCD}$ & 16.88 & -3.93 & 000 & $\mathrm{AB}$ \\
\hline DL (p 5\%) & & & 1.95 & & & & 1.95 & & & DL (p & $\%)=$ & 1.38 \\
\hline DL (p 1\%) & & & 2.57 & & & & 2.57 & & & DL (p & $\%)$ & 1.82 \\
\hline DL (p 0.1\%) & & & 3.29 & & & & 3.29 & & & DL (p & $0.1 \%)$ & $=2.33$ \\
\hline
\end{tabular}

application of conventional and unconventional treatments. After analyzing the data in 2013, the variants that were applied to Terra Sorb Foliar products and Maxiroot, the differences were significantly negative. Other products have significant differences. The data presented in 2013, follows that any treatment applied to unconventional products have significant differences from the control positive. In 2014, the application of treatment products, bionic Biostar, Glutaxim, Terra Sorb Foliar and Maxiroot very significant differences were recorded negative. Average yields in the experimental years all varieties mid early in the study (Table 2), obtained by interpreting the results using Duncan test highlights that the application of treatment products Bionat, Glutaxim, Terra Sorb Foliar and Maxiroot were registered significant 
differences negative, very significant negative. These data obtained leads us to conclude that the climatic conditions in which the experiments took place (uneven distribution of rainfall and higher temperatures than the annual average during the growing season), applying the treatments unconventional had very negative effects in terms production.

\section{CONCLUSIONS}

Mid early potato varieties studied (Amelia, Robusta, Christian, Dacia, Impala and Roclas) reacted differently to the application of conventional and unconventional treatments with products.

Table 3 presents the yields obtained from the 6 mid early varieties studied, the two experimental years, the application of treatment. Further data will be analyzed each year experimental basis, and the average yields obtained in the two experimental years.

Analyzing the data in Table 3, after applying treatments with conventional and unconventional products in 2013, it is noted that, mid early varieties studied behaved very differently in terms of production.

Variety Amelia, when applying unconventional treatments Biostar product, recorded a production increase higher compared to control (Bordeaux mixture), the differences being very significant positive significant positive respectively compared to the control.

If Robusta variety in 2013, tratmentele applied unconventional products did not influence the productivity of the variety, the differences are insignificant compared to the control.

Compared to the varieties mentioned, the Christian variety treatments, reacted negatively in terms of output. The only treatment that has positively influenced unconventional production is the Bionat, in which case the difference was recorded significant positive compared to the control. When applying treatments with other products, the differences were not significant compared to the control.

Dacia mid early potato variety, among the six studied, was the only one who reacted very negatively to the unconventional application of treatment products.

Impala reacted negatively semi-early variety, in terms of production, the application of unconventional treatments Bionat product. Where the other treatments with unconventional products, the differences were insignificant in 2013 compared trainer.

As shown in Table 3, obtained by interpreting reultatelor using multiple comparison test (Test Duncan), mid early variety Roclas reacted positively to the application of treatment product unconventional Glutaxim, the differences are distinct significantly positive or significantly positive compared with its trainer. When applying other products, the differences were not significant compared to the control.

The data in Table 3 we can say that in 2013, applying unconventional treatments Bionat and Glutaxim products have positively impacted production potential of varieties. This can be justified by the fact that 2013, in terms of climate was unfavorable with temperatures higher than the annual average and the uneven distribution of rainfall, especially during the potato vegetation. Nutrients contained unconventional products, in conjunction with the precocity group they belong to varieties sudiu taken have had a positive influence on production rather unfavorable climatic conditions for potato cultivation.

In experimental year 2014 mid early varieties behaved differently from the 2013 application treatments. Products of unconventional stands Biostar, increases production of the variety Amelia registered variant treated with this product is distinctly significant positive compared to the control, while the product unconventional Bionat had a negative influence on production, the difference recorded being significantly negative from the witness .

If Robusta variety is remarkable unconventional Atonik product, the differences being very significant positive resect positive significantly distinct from the witness.

Variety Christian reacted very well to the application of unconventional treatments Bionat and Biostar products, production increases very significantly positive compared with its treatment has been applied to the product Bordeaux mixture (control).

If the first three varieties have reacted favorably to the application of conventional and unconventional treatments products, as shown in Table 3, Dacia varieties, Impala and Roclas reacted unfavorably applied to most products. 


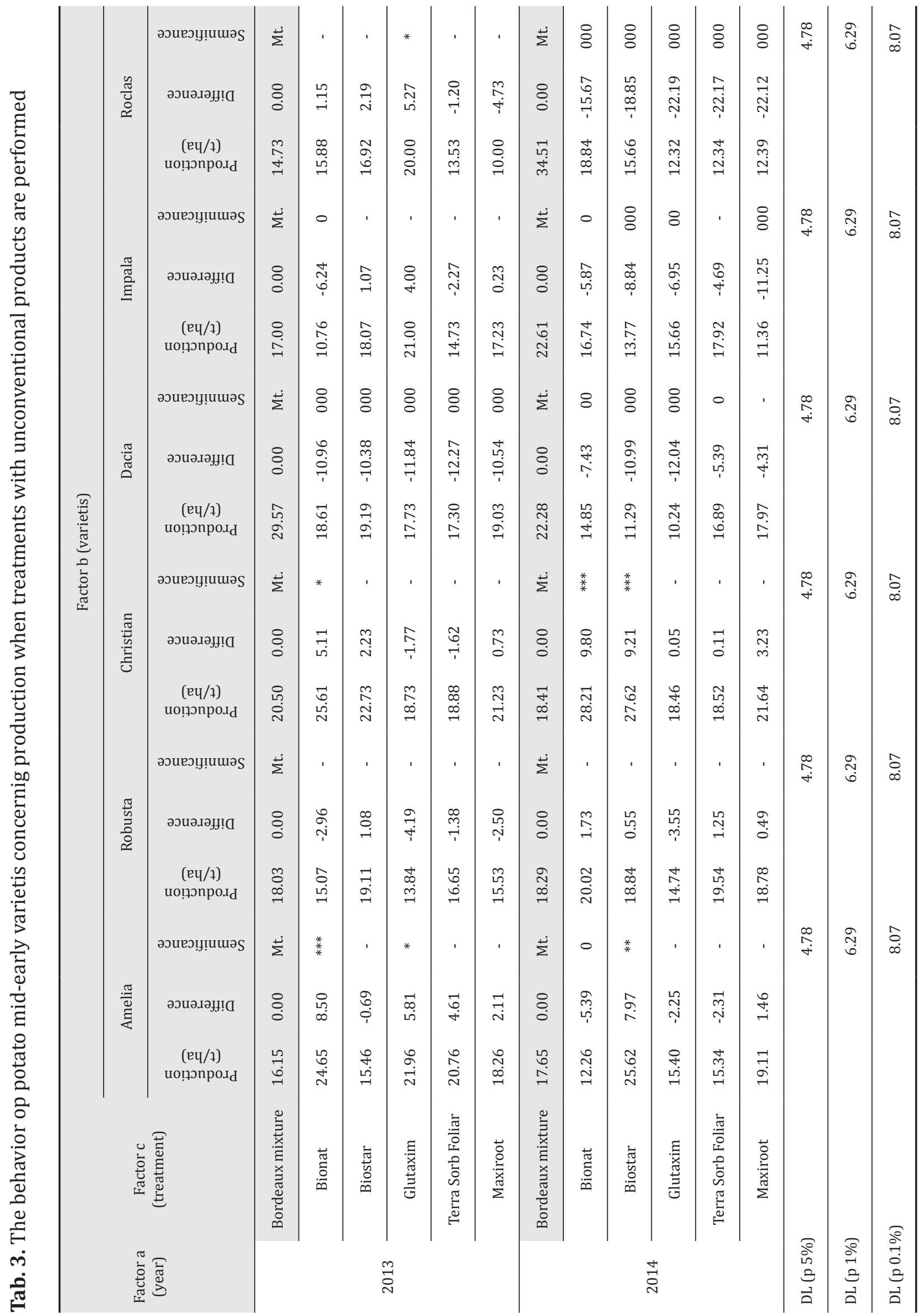


Variety Dacia reacted unfavorably to most unconventional applied products, recorded very significant differences from the control negative.

If Impala variety, most treatments applied to unconventional products have negatively affected the productive potential of the variety, the differences being very significantly negative or significantly negative distinct from the control (Table 3).

Of the six varieties studied, Roclas variety is distinguished by the fact that he reacted negatively to the application of the 6 treatments.

As is clear from the data presented in Table 3 mid early varieties studied behaved differently in the two experimental years. If 2013 Amelia variety of unconventional react favorably after treatment bionic 2014 reacted unfavorably same variety. This can be justified perhaps by the fact that in two experimental years, the climatic conditions were different. In terms of rainfall, 2014 was rich, and in this case, probably applying unconventional Bionat product would not be appropriate. Dacia varieties and Impala reacted unfavorably to the application of treatment in two experimental years, with steadied that in 2014, the variety Impala reacted unfavorably to the application of most products.
We conclude that this is due to the effects of remineralization, rebalancing and regenerating metabolic processes of plants, nutrient content of products in primary, secondary and micronutrients that act on the plant cells, even in relatively unfavorable climatic conditions for potato cultivation. Besides the favorable effects These products help to intensify the process of photosynthesis, thereby hastening the synthesis corofilei and other proteins (carbohydrate) cells and due to this reaction, accelerates metabolism of plants, which leads to increased root system so deep and the number of bristles absorbing, increasing the capacity of absorption of nutrients in the soil solution.

Acknowledgements: This paper was published under the frame of European Social Fund, Human Resources Development Operational Programme 2007-2013, projectno. POSDRU/159/1.5/S/132765.

\section{REFERENCES}

1. Mogârzan A,. Morar G, Stefa M. (2004). Fitotehnie, Ed. Ion Ionescu de la Brad, Iaşi

2. Ştefan V, (2005). Cartoful: tehnici de cultivare, Ed. Nemira, București 